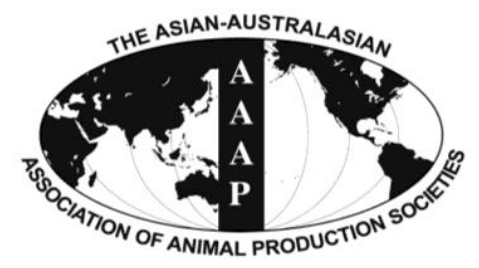

Asian-Aust. J. Anim. Sci.

Vol. 25, No. $9: 1269$ - 1275

September 2012

www.ajas.info

http://dx.doi.org/10.5713/ajas.2012.12318

\title{
Soluble Non-ammonia Nitrogen in Ruminal and Omasal Digesta of Korean Native Steers Supplemented with Soluble Proteins
}

\author{
C. W. Choi ${ }^{*}$, K. H. Kim ${ }^{1}$, S. S. Chang ${ }^{1}$ and N. J. Choi $^{2}$ \\ Department of Animal Resources, Institute of Life and Environment, Daegu University, \\ Jillyang, Gyeongsan 712-714, Korea
}

\begin{abstract}
An experiment was conducted to study the effect of soluble protein supplements on concentration of soluble nonammonia nitrogen (SNAN) in the liquid phase of ruminal (RD) and omasal digesta (OD) of Korean native steers, and to investigate diurnal pattern in SNAN concentration in RD and OD. Three ruminally cannulated Korean native steers in a $3 \times 3$ Latin square design consumed a basal diet of rice straw and corn-based concentrate (control), and that supplemented (kg/d DM basis) with intact casein (0.24; IC) or acid hydrolyzed casein $(0.46$; AHC). Ruminal digesta was sampled using a vacuum pump, whereas OD was collected using an omasal sampling system at $2.0 \mathrm{~h}$ intervals after a morning feeding. The SNAN fractions (free amino acid (AA), peptide and soluble protein) in RD and OD were assessed using the ninhydrin assay. Concentrations of free AA and total SNAN in RD were significantly $(\mathrm{p}<0.05)$ lower than those in OD. Although free AA concentration was relatively high, mean peptide was quantitatively the most important fraction of total SNAN in both RD and OD, indicating that degradation of peptide to AA rather than hydrolysis of soluble protein to peptide or deamination may be the most limiting step in rumen proteolysis of Korean native steers. Diurnal variation in peptide concentration in OD for the soluble protein supplemented diets during the feeding cycle peaked $2 \mathrm{~h}$ post-feeding and decreased thereafter whereas that for the control was relatively constant during the entire feeding cycle. Diurnal variation in peptide concentration was rather similar between RD and OD. (Key Words: Soluble Non-ammonia Nitrogen, Omasal Digesta, Diurnal Variation, Korean Native Steer)
\end{abstract}

\section{INTRODUCTION}

Studies of feed evaluation using the nylon bag method were performed based on an assumption that the ' $a$ fraction', which is rapidly degradable nitrogen $(\mathrm{N})$ in the rumen, of feed was infinitely degraded and consequently that only insoluble feed $\mathrm{N}$ could escape the rumen (Ørskov and McDonald, 1979; Madsen et al., 1995; Volden and Harstad, 1995). Many in vivo studies, however, reported that a substantial soluble non-ammonia N (SNAN) concentration may escape the rumen of dairy cows (Chen et al., 1987a, 1987b; Robinson and McQueen, 1994), which is inconsistent with the assumption of the nylon bag studies. For example, Choi et al. (2002b) reported that approximately $110 \mathrm{mg} / \mathrm{L}$ of SNAN was detected in omasal

\footnotetext{
* Corresponding Author: Chang Weon Choi. Tel: +82-53-8506721, Fax: +82-53-850-6729, E-mail: changchoi@daegu.ac.kr ${ }^{1}$ National Institute of Animal Science, RDA, 441-706, Korea.

2 Department of Animal Science, Chonbuk National University, Jeonju, 561-756, Korea.

Submitted Jun. 8, 2012; Accepted Jun. 20, 2012; Revised Jul. 3, 2012
}

digesta of dairy cows supplemented with skimmed milk powder, which completely disappeared from nylon bags during the zero $\mathrm{h}$ washing procedure (Choi, 2002). Chen et al. (1987a) also reported that an increase in crude protein (CP) of diets (14.5 to $17.5 \%$ DM basis) did not affect flow of peptide and soluble protein in RD. In addition, Broderick and Wallace (1988) showed a peak of ruminal peptide concentration immediately after feeding when casein was fed.

The SNAN data in the studies described above (Chen et al., 1987a, 1987b; Broderick and Wallace, 1988; Robinson and McQueen, 1994) were achieved from mainly dairy cows fed relatively high CP. It may be in general accepted that a considerable amount of SNAN from dairy cows fed high $\mathrm{CP}$ diets, even soluble protein and non-protein $\mathrm{N}$, can escape ruminal degradation (Choi et al., 2002b). Besides, the SNAN escaping ruminal degradation may increase milk production including milk protein synthesis (Choi et al., 2002b). However, few SNAN studies using beef cattle fed relatively low $\mathrm{CP}$ diets compared to dairy cows were available. Quantification of SNAN from beef cattle may be 
important because Swanson et al. (2002) and Richard et al. (2003) reported that abomasal infusion of glucose (and/or starch) with soluble protein increased glucose (and/or starch) utilization in the small intestine of beef steers compared with starch infusion alone. Thus, the more SNAN escaping the rumen may increase intramuscular fat of beef cattle through high glucose utilization because Smith and Crouse (1984) as reported that glucose was primarily utilized for intramuscular fat synthesis compared to other carbon sources, i.e. acetate, lactate, etc.

The present study, therefore, aimed to study the effect of soluble protein supplements on the concentration of SNAN in ruminal (RD) and omasal digesta (OD) of Korean native beef cattle fed rice straw and corn-based concentrate supplemented with different soluble proteins and to investigate diurnal patterns in the SNAN concentration in RD and OD.

\section{MATERIALS AND METHODS}

\section{Animals and diets}

Three Korean native beef steers weighing on an average $779(\mathrm{SE} \pm 21.1) \mathrm{kg}$ and fitted with $100 \mathrm{~mm}$ i.d. ruminal cannula were used in a $3 \times 3$ Latin square experiment. The animals were housed individually in $3 \times 3.2 \mathrm{~m}$ pens with concrete floors in a temperature and light controlled $\left(23^{\circ} \mathrm{C}\right.$ and $16 \mathrm{~h}$ of light/ $8 \mathrm{~h}$ of dark, respectively) room with water and a trace-mineralized salt block available throughout the experiments. The steers were weighed before each period. They were provided with two equal meals daily at 09:00 and 17:00 h.

The steers were offered rice straw and corn-based concentrate ad libitum during an adaptation period, and then the DMI was restricted to $90 \%$ of the ad libitum intake. A basal diet (\% DM) consisted of rice straw (31.3) and concentrate (68.8) (control). Concentrate (\% DM) contained corn (50.8), wheat bran (38.0), soybean meal (3.0), rapeseed meal (2.0), molasses (2.0), limestone (1.5), salt (0.4) and vitamin and minerals (0.3). Part of the basal diet was replaced $(\mathrm{kg} / \mathrm{d})$ by one of two protein supplements as follows: intact casein (0.24) (IC; $100 \%$ protein), or acid hydrolyzed casein (0.46) (AHC; 80\% AA+20\% peptide).

\section{Sampling procedures and chemical analysis}

Each period lasted $21 \mathrm{~d}$. Feed intake was recorded daily. Representative samples of feeds were collected on d 15 to 21, pooled, subsampled, dried and ground through a 1-mm screen with a Wiley mill (Thomas Scientific, Model 4, NJ, USA) for analysis. Feed DM concentration was determined using a forced-air oven for $18 \mathrm{~h}$ at $105^{\circ} \mathrm{C}$. Approximate analysis of experimental feeds was performed according to AOAC (1990). To estimate SNAN fractions in digesta, RD and OD were collected at $0,2,4,6$, and $8 \mathrm{~h}$ post-feeding on d 21. RD was sampled from the rumen via the ruminal cannula, and OD was collected from the omasal canal by means of a plastic tube (14 mm i.d.) connected to a pump according to procedures outlined by Huhtanen et al. (1997), with the exceptions as follows: i) larger sampling tube (14 vs $9.5 \mathrm{~mm}$ i.d.), ii) solenoid valves instead of a three way ball valve to control vacuum and pressure phases in a pump and iii) a $0.5 \mathrm{~kg}$ weight inserted into the abomasum two secure the sampling device in the omasum. Approximately $300 \mathrm{ml}$ samples of RD and OD were filtered through four layers of cheesecloth and saturated $\mathrm{HgCl}_{2}$ added to prevent microbial activity. Filtrates of RD and $\mathrm{OD}$ were centrifuged at $1,000 \times g$ for $10 \mathrm{~min}$ at $4^{\circ} \mathrm{C}$, and the supernatant was decanted into a fresh tube followed by high-speed centrifugation $\left(10,000 \times g, 30 \mathrm{~min}, 4^{\circ} \mathrm{C}\right)$ to remove small particles and rumen microbes. The supernatant was precipitated with trichloroacetic acid (TCA) (final concentration $5 \% \mathrm{w} / \mathrm{v}$ ), placed in ice overnight and highspeed centrifuged $\left(10,000 \times g, 30 \mathrm{~min}, 4^{\circ} \mathrm{C}\right)$. Different $\mathrm{N}$ fractions (free AA, peptide and soluble protein) of SNAN in the liquid phase of RD and OD were assessed using a ninhydrin assay. Details of SNAN fractions analyses have previously been described by Choi (2002). In brief, SNAN within RD and OD was fractionated as follows: i) free AA: estimated from the supernatant without acid-hydrolysis, ii) peptide: estimated from hydrolysed supernatant $(6 \mathrm{M} \mathrm{HCl}$, $24 \mathrm{~h}, 110^{\circ} \mathrm{C}$ ) minus free $\mathrm{AA}$ and iii) soluble protein: estimated from hydrolysis of TCA-precipitate, respectively. All SNAN fractions were corrected for ammonia $\mathrm{N}$ except for soluble protein because TCA-precipitate was assumed to contain negligible amounts of ammonia $\mathrm{N}$.

\section{Statistical analysis}

Data on intake of dietary ingredients were fitted using the MIXED procedure of SAS (2002) according to the following statistical model:

$$
\mathrm{Y}_{\mathrm{ijk}}=\mu+\mathrm{A}_{\mathrm{i}}+\mathrm{P}_{\mathrm{j}}+\mathrm{D}_{\mathrm{k}}+\mathrm{e}_{\mathrm{ijk}}
$$

where $\mathrm{A}$ is a random effect of animal, and $\mathrm{P}$ and $\mathrm{D}$ are the fixed effects of period and diet, respectively.

Data on SNAN fractions of RD and OD determined at each sampling interval were fitted using the MIXED procedure of SAS (2002) for repeated measures according to the following statistical model:

$$
\mathrm{Y}_{\mathrm{ijkl}}=\mu+\mathrm{A}_{\mathrm{i}}+\mathrm{P}_{\mathrm{j}}+\mathrm{D}_{\mathrm{k}}+\mathrm{e}_{\mathrm{ijk}}+\mathrm{T}_{\mathrm{l}}+(\mathrm{A} \times \mathrm{T})_{\mathrm{il}}+(\mathrm{P} \times \mathrm{T})_{\mathrm{jl}} \mathrm{t}(\mathrm{D} \times \mathrm{T})_{\mathrm{kl}}+\mathrm{e}_{\mathrm{ijkl}}
$$

where $\mathrm{T}$ is a fixed effect of time after feeding, and $\mathrm{A} \times \mathrm{T}$, $\mathrm{P} \times \mathrm{T}$ and $\mathrm{D} \times \mathrm{T}$ are animal by time, period by time and diet by time interactions, respectively. In the repeated measures models, animal, animal by time interaction and error terms $\left(\mathrm{e}_{\mathrm{ijk}}\right.$ defined as between unit error and $\mathrm{e}_{\mathrm{ijkl}}$ as within unit 
Table 1. Chemical composition of experimental feeds

\begin{tabular}{|c|c|c|c|c|}
\hline & Rice straw & Concentrate & Intact casein & Acid hydrolysates \\
\hline \multicolumn{5}{|c|}{ Composition, \% Dry matter (DM) } \\
\hline $\mathrm{DM}(\%)$ & 93.56 & 88.13 & 92.94 & 92.28 \\
\hline Crude protein & 4.45 & 14.66 & 87.11 & 49.13 \\
\hline Ether extract & 1.34 & 3.74 & 3.68 & 0.10 \\
\hline Crude fiber & 37.04 & 5.86 & 1.00 & 0.37 \\
\hline Crude ash & 11.90 & 5.12 & 5.24 & 44.93 \\
\hline
\end{tabular}

The water and vitamin and mineral block were available at all times.

Table 2. Intake of dietary ingredients

\begin{tabular}{|c|c|c|c|c|c|c|c|c|}
\hline \multirow{2}{*}{ Item } & \multicolumn{3}{|c|}{$\operatorname{Diet}^{1}$} & \multirow{2}{*}{ SEM $^{2}$} & \multicolumn{4}{|c|}{ Statistical significance $^{3}$} \\
\hline & Control & IC & $\mathrm{AHC}$ & & $\mathrm{C} 1$ & $\mathrm{C} 2$ & C3 & $\mathrm{C} 4$ \\
\hline \multicolumn{9}{|c|}{ Dry matter intake (DMI, kg/d) } \\
\hline Rice straw & 1.78 & 1.80 & 1.68 & 0.068 & 0.48 & 0.14 & 0.70 & 0.19 \\
\hline Concentrate & 3.91 & 3.63 & 3.47 & 0.084 & 0.07 & 0.29 & 0.14 & 0.06 \\
\hline Intact casein & & 0.24 & & & & & & \\
\hline Acid hydrolyzed casein & & & 0.46 & & & & & \\
\hline Total DMI & 5.68 & 5.67 & 5.61 & 0.121 & 0.29 & 0.21 & 0.77 & 0.17 \\
\hline Crude protein & 0.65 & 0.82 & 0.81 & 0.019 & 0.006 & 0.369 & 0.007 & 0.008 \\
\hline
\end{tabular}

${ }^{1}$ Control = Rice straw+concentrate; IC = Rice straw+concentrate+intact casein; AHC = Rice straw+concentrate+acid hydrolyzed casein.

${ }^{2} \mathrm{SEM}=$ Standard error of the mean

${ }^{3} \mathrm{C} 1=$ Effect of casein supplements; $\mathrm{C} 2=$ Effect of casein types; $\mathrm{C} 3=$ Effect of intact casein; $\mathrm{C} 4=$ Effect of acid hydrolyzed casein.

error) are assumed to be multivariate normally distributed random effects with AR (1) covariance structure. Orthogonal contrasts used in post-ANOVA comparisons were as follows; i) effect of casein supplements (control vs IC+AHC), ii) effect of casein types (IC vs AHC), iii) effect of intact casein (control vs IC) and iv) effect of acid hydrolyzed casein (control vs AHC), respectively.

\section{RESULTS AND DISCUSSION}

\section{Feeds}

The chemical composition of experimental feeds is given in Table 1. Experimental animals consumed rice straw and concentrates as planned (Table 2). Soluble protein supplements had no effect $(p>0.05)$ on total DMI, but increased CP intake $(\mathrm{p}=0.006)$.

\section{Metabolism of SNAN}

Concentration of SNAN fractions in the liquid phase of $\mathrm{RD}$ and $\mathrm{OD}$ is given in Table 3. Soluble protein supplements did not affect $(\mathrm{p}>0.05)$ free AA concentration in RD. These results contrast with those of Choi et al. (2002b), in which dietary soluble protein (skimmed milk powder and wet distiller's soluble) increased free AA in RD

Table 3. Effect of soluble protein supplements on concentration $(\mathrm{mg} / \mathrm{L})$ of soluble non-ammonia nitrogen fractions in ruminal (RD) and omasal digesta (OD) of Korean native steers

\begin{tabular}{|c|c|c|c|c|c|c|c|c|c|}
\hline \multirow{2}{*}{ Item } & \multicolumn{3}{|c|}{ Diet $^{1}$} & \multirow{2}{*}{$\mathrm{SEM}^{2}$} & \multicolumn{5}{|c|}{ Statistical significance $^{3}$} \\
\hline & Control & $\mathrm{IC}$ & AHC & & $\mathrm{C} 1$ & $\mathrm{C} 2$ & $\mathrm{C} 3$ & $\mathrm{C} 4$ & Site \\
\hline \multicolumn{10}{|c|}{ Free amino acids (AA) } \\
\hline $\mathrm{RD}$ & 47.3 & 45.1 & 47.9 & 1.25 & 0.44 & 0.10 & 0.15 & 0.61 & $46.8^{\mathrm{a}}$ \\
\hline OD & 48.2 & 64.2 & 61.9 & 6.06 & 0.07 & 0.79 & 0.09 & 0.14 & $58.1^{\mathrm{b}}$ \\
\hline \multicolumn{10}{|c|}{ Peptide } \\
\hline $\mathrm{RD}$ & 63.7 & 85.7 & 82.5 & 5.23 & 0.02 & 0.67 & 0.02 & 0.04 & 77.3 \\
\hline OD & 65.6 & 82.9 & 96.4 & 4.28 & 0.002 & 0.06 & 0.02 & $<0.001$ & 81.6 \\
\hline \multicolumn{10}{|c|}{ Soluble protein } \\
\hline $\mathrm{RD}$ & 20.1 & 18.5 & 20.7 & 1.23 & 0.73 & 0.28 & 0.40 & 0.78 & 19.8 \\
\hline OD & 18.8 & 19.2 & 18.7 & 0.88 & 0.85 & 0.62 & 0.68 & 0.93 & 18.9 \\
\hline \multicolumn{10}{|l|}{ SNAN } \\
\hline $\mathrm{RD}$ & 131.2 & 149.3 & 151.1 & 5.31 & 0.03 & 0.82 & 0.06 & 0.05 & $143.9^{c}$ \\
\hline OD & 132.6 & 166.3 & 177.0 & 5.85 & 0.004 & 0.25 & 0.01 & 0.004 & $158.6^{\mathrm{d}}$ \\
\hline
\end{tabular}

${ }^{1}$ Control = Rice straw+concentrate; IC = Rice straw+concentrate+intact casein; AHC = Rice straw+concentrate+acid hydrolyzed casein .

${ }^{2} \mathrm{SEM}=$ Standard error of the mean.

${ }^{3} \mathrm{C} 1=$ Effect of casein supplements; $\mathrm{C} 2=$ Effect of casein types; $\mathrm{C} 3=$ Effect of intact casein; $\mathrm{C} 4$ = Effect of acid hydrolyzed casein. 
of dairy cows fed grass silage based diets. Compared with control, IC tended $(\mathrm{p}=0.09)$ to increase free AA concentration in OD. Relatively high concentration of free AA in both RD and OD is consistent with a previous study (Choi et al., 2002b). However, Choi et al. (2002a) reported a relatively low concentration of free AA (mean $15.9 \mathrm{mg}$ $\mathrm{N} / \mathrm{l}$ ) in OD. Also, Nolan (1993) reviewed that free AA concentration was very low even immediately after feeding.

Soluble protein supplements statistically increased peptide concentration in $\mathrm{RD}(\mathrm{p}=0.02)$ and OD $(\mathrm{p}=0.002)$, whereas the protein types did not affect $(\mathrm{p}>0.05)$ peptide $\mathrm{N}$. This observation is rather similar to that of Choi et al. (2002b), where soluble protein tended to increase peptide $\mathrm{N}$ despite lack of significance. In the study of Choi et al. (2002b), peptide $\mathrm{N}$ was not affected by soluble protein types. Absolute value of peptide in RD in the present study $(77.3 \mathrm{mg} / \mathrm{L})$ was relatively lower than published values $(82$ to $111 \mathrm{mg} / \mathrm{L}$ ) (Chen et al., 1987a; Robinson and McQueen, 1994; Robinson et al., 1998). This may be because the previous studies have analysed free AA and peptide together, whereas we analysed net peptide. If free $\mathrm{AA}$ and peptide are pooled together, the sum $(124.1 \mathrm{mg} / \mathrm{L})$ in the present study is slightly higher than the previous value cited above. Despite relatively high free AA concentration, peptide $\mathrm{N}$ in $\mathrm{RD}$ and $\mathrm{OD}$ averaging 77.3 and $81.6 \mathrm{mg} / \mathrm{L}$, respectively, was quantitatively the most important $\mathrm{N}$ in SNAN fractions. This result clearly supports our suggestion that degradation of peptide to AA may be the rate-limiting step in protein degradation in the rumen (Choi et al., 2002a, 2002b; Oh et al., 2008). Thus, the previous observation that hydrolysis of protein to peptide or deamination may be the rate-limiting step in rumen proteolysis (Wright and Hungate, 1967; Chen et al., 1987b; Van Straalen and Tamminga, 1990) is not valid.

Neither soluble protein supplements nor their types affect $(p>0.05)$ soluble protein concentration in either RD or OD. Mean concentration of soluble protein in RD (19.8 $\mathrm{mg} / \mathrm{L})$ and OD (18.9) are in good agreement with reported values (12 to $37 \mathrm{mg} / \mathrm{L}$ ) by Robinson and McQueen (1994), Robinson et al. (1998) and Oh et al. (2008). Inconsistent with the present result, Choi et al. (2002b) reported extremely low soluble protein concentration in RD and OD (1.0 and $1.2 \mathrm{mg} / \mathrm{L}$, respectively) when different proteins were supplemented to dairy cows.

A considerable amount of SNAN fractions including peptide and free AA in OD determined from beef cattle in the present study may be important because soluble protein infusing into the abomasum increased glucose and/or starch utilization in the small intestine of beef steers (Richard et al., 2002; Swanson et al., 2002). Smith and Crouse (1984) observed that glucose was primarily utilized for bovine intramuscular fat synthesis rather than acetate, lactate, etc. In addition, starch digestion in the small intestine is more energetically efficient than its fermentation in the rumen (Richards et al., 2003). Taniguchi et al. (1995) also suggested that protein supply can improve starch digestion in the small intestine of beef cattle. Further studies on relationship between omasal SNAN concentration and intramuscular fat synthesis including starch utilization in the small intestine of beef cattle is required.

\section{Rumen vs omasum in SNAN}

In the present study, free AA in OD was significantly $(\mathrm{p}<0.05)$ higher than that in $\mathrm{RD}$, supporting a similar result of Kim et al. (2009), where Korean native steers supplemented with protein had higher free AA in OD than that in RD (24.9 vs $20.1 \mathrm{mg} \mathrm{N} / \mathrm{L}$ ). In the present study, no statistical significance $(\mathrm{p}>0.05)$ in peptide concentration between RD and OD was observed. This is not in agreement with previous study (Choi et al., 2002b), where peptide in OD was considerably higher than that in RD. The discrepancy between the present and the previous studies is unclear; however this may be related to the soluble protein and CP levels in experimental diets. In other words, Choi et al. (2002b) used grass silage as a basal diet including high soluble $\mathrm{N}$ and relatively high $\mathrm{CP}$ (approximately 15.3 to $17.6 \%$ ) for dairy cows in lactation. In the present study, intact and acid hydrolyzed casein as protein supplements were mainly in the forms of soluble protein and AA including $20 \%$ peptide, respectively, thus peptide concentrations did not clearly differ between RD and OD. In addition, the steers in the present study consumed relatively low CP (11.4 to $14.4 \%$, Table 2$)$. Similar to the peptide results, soluble protein concentration between RD and OD did not statistically differ ( $p>0.05)$.

\section{Diurnal variation in SNAN}

Diurnal variation in mean concentration of SNAN fractions in RD are shown in Figure 1. Dietary soluble protein supplements did not affect $(p>0.05)$ diurnal variation in free AA concentration. Diurnal variation in free AA concentration for all groups was relatively constant with no clear peaks during an entire feeding cycle. This result may support a previous observation that ruminal free AA concentration was relatively low even immediately post-feeding (Nolan, 1993). Broderick and Wallace (1988) also reported that diurnal variation in free AA was relatively constant during a feeding cycle when sheep consumed $67 \%$ ryegrass hay and $33 \%$ concentrate with ovalbumin supplementation. Mean concentration of peptide in RD appeared to be highest at $2 \mathrm{~h}$ post-feeding and declined thereafter. Compared with control, mean peptide concentration for IC and AHC was numerically higher during the entire feeding cycle. Diurnal variation in ruminal peptide concentration in RD is consistent with previous studies (Robinson and McQueen, 1994; Robinson et al., 
1998; Oh et al., 2008) in which the diurnal variation peaked immediately after feeding and declined thereafter. In addition, Broderick and Wallace (1988) reported that peptide reached a maximum immediately after feeding when casein was supplemented, even though diurnal variation in peptide concentration was rather constant throughout a feeding cycle in sheep fed hay and corn-based concentrate. As with the ruminal free AA pattern, soluble protein concentration was relatively constant throughout the feeding period. In contrast with the present results, previous studies showed clear peaks of soluble protein concentration at 1 to $3 \mathrm{~h}$ post-feeding (Robinson and McQueen, 1994; Robinson et al., 1998; Oh et al., 2008).

Unlike the ruminal free AA, when soluble protein was
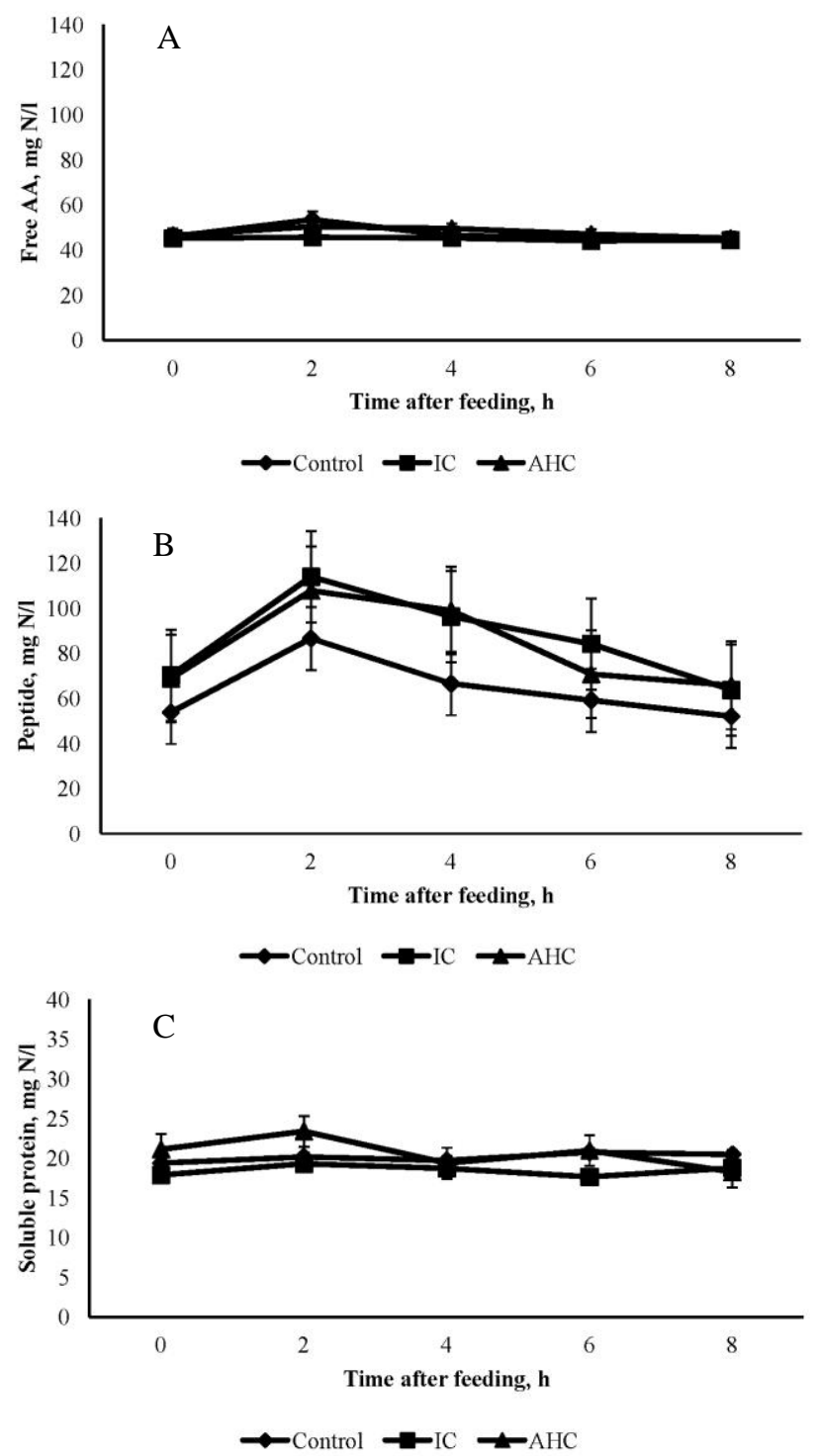

Figure 1. Diurnal pattern in concentration of free amino acids (AA) (A), peptide (B) and soluble protein (C) in the liquid phase of ruminal digesta (RD) during a feeding cycle as influenced by soluble protein supplements (Markers indicate no supplement $(\diamond)$, intact casein ( $\mathbf{})$ and acid hydrolyzed casein $(\mathbf{\Lambda})$, respectively). supplemented diurnal variation in omasal free AA concentration was the highest at $2 \mathrm{~h}$ after feeding, declined till $4 \mathrm{~h}$ and then remained relatively constant throughout the remainder of the feeding cycle. This result is similar to a previous result reported by $\mathrm{Oh}$ et al. (2008) in which dietary protein supplements showed clear peaks in omasal free AA concentration immediately post-feeding. In contrast, rapeseed meal supplementation did not show clear peaks of omasal free AA concentration in dairy cows fed grass based diets (Choi, 2007). Diurnal variation in peptide concentration in OD being similar with that in RD (Figures 1 and 2 ) and appeared to be highest at $2 \mathrm{~h}$ post feeding and declined thereafter except for the control. This result is consistent with previous results (Choi et al., 2002c; Oh et
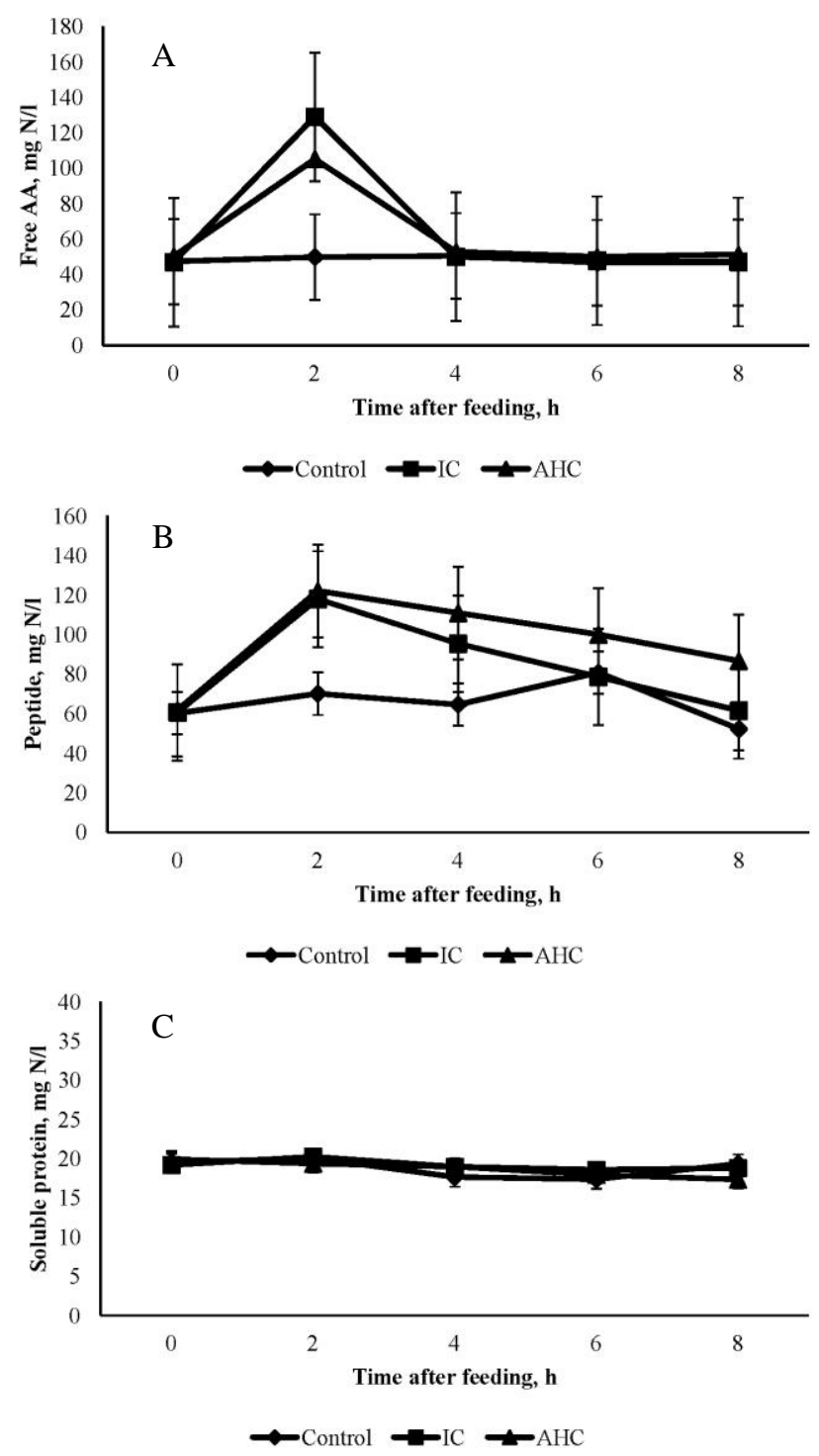

Figure 2. Diurnal pattern in concentration of free amino acids (AA) (A), peptide (B) and soluble protein (C) in the liquid phase of omasal digesta (OD) during a feeding cycle as influenced by soluble protein supplements (Markers indicate no supplement $(\bullet)$, intact casein ( $\boldsymbol{\square})$ and acid hydrolyzed casein $(\boldsymbol{\Delta})$, respectively). 
al., 2008) where various protein supplements showed a peptide peak immediately post-feeding. The present peptide pattern may support a previous observation (Oh et al., 2008) that dietary soluble proteins were rapidly degraded to peptides in the rumen shortly after consumption. Protein supplements did not affect diurnal variation in soluble protein concentration entering into the omasum. Soluble protein concentration was relatively constant throughout the feeding period. Consistent with the present results, some studies showed no clear peaks of soluble protein concentration during the entire feeding cycle (Choi and Choi, 2003; Oh et al., 2008).

\section{ACKNOWLEDGEMENTS}

This study was supported by Cooperation Research Project (No. PJ007800062012), Rural Development Administration, Republic of Korea.

\section{REFERENCES}

AOAC. 1990. Official methods of analysis. 15th ed. Association of Official Analytical Chemists. Washington, DC, USA.

Broderick, G. A. and R. J. Wallace. 1988. Effects of dietary nitrogen source on concentrations of ammonia, free amino acids and fluorescamine-reactive peptides in the sheep rumen. J. Anim. Sci. 66:2233-2238.

Chen, G., C. J. Sniffen and J. B. Russell. 1987a. Concentration and estimated flow of peptides from the rumen of dairy cattle: Effects of protein quantity, protein solubility, and feeding frequency. J. Dairy Sci. 70:983-992.

Chen, G., J. B. Russell and C. J. Sniffen. 1987b. A procedure for measuring peptides in rumen fluid and evidence that peptide uptake can be a rate-limiting step in ruminal protein degradation. J. Dairy Sci. 70:1211-1219.

Choi, C. W. 2002. Assessment of the flow of soluble dietary nonammonia nitrogen escaping degradation in the rumen of dairy cows fed grass silage based diets. Doctoral dissertation. University of Helsinki. Department of Animal Science. Viikki. Finland.

Choi, C. W. 2007. Diurnal patterns in the flow of escapable soluble non-ammonia nitrogen fractions in omasal digesta as influenced by barley and rapeseed meal supplementation in cows fed grass silage based diet. J. Anim. Sci. Technol. 49:341-350.

Choi, C. W. and C. B. Choi. 2003. Flow of soluble non-ammonia nitrogen in the liquid phase of digesta entering the omasum of dairy cows given grass silage based diets. Asian-Aust. J. Anim. Sci. 16:1460-1468.

Choi, C. W., S. Ahvenjärvi, A. Vanhatalo, V. Toivonen and P. Huhtanen. 2002a. Quantitation of the flow of soluble nonammonia nitrogen entering the omasal canal of dairy cows fed grass silage based diets. Anim. Feed Sci. Technol. 96:203-220.

Choi, C. W., A. Vanhatalo, S. Ahvenjärvi and P. Huhtanen. 2002b. Effects of several protein supplements on flow of soluble nonammonia nitrogen from the forestomach and milk production in dairy cows. Anim. Feed Sci. Technol. 102:15-33.
Choi, C. W., A. Vanhatalo and P. Huhtanen. 2002c. Concentration and estimated flow of soluble non-ammonia nitrogen entering the omasum of dairy cows as influenced by different protein supplements. Agric. Food Sci. Finl. 11:79-91.

Huhtanen, P., P. G. Brotz and L. D. Satter. 1997. Omasal sampling technique for assessing fermentative digestion in the forestomach of dairy cows. J. Anim. Sci. 75:1380-1392.

Kim, J. H., Y. K. Oh, K. H. Kim, C. W. Choi, S. K. Hong, Y. J. Seol, D. H. Kim, G. C. Ahn, M. K. Song and K. K. Park. 2009. Effects of protein supply from soyhulls and wheat bran on ruminal metabolism, nutrient digestion and ruminal and omasal concentrations of soluble non-ammonia nitrogen of steers. Asian-Aust. J. Anim. Sci. 22:1267-1278.

Madsen, J., T. Hvelplund, M. R. Weisbjerg, J. Bertilsson, I. Olsson, R. Spörndly, O.M. Harstad, H. Volden, M. Tuori, T. Varvikko, P. Huhtanen and B. L. Olafsson. 1995. The AAT/PBV protein evaluation system for ruminants. A revision. Norw. J. Agric. Sci. (Suppl.) 19:1-37.

Nolan, J. V. 1993. Nitrogen kinetics. In: Quantitative aspects of ruminant digestion and metabolism (Ed. J. M. Forbes and J. France). CAB International Wallingford, Oxon, UK, pp. 123143.

Oh, Y. K., J. H. Kim, K. H. Kim, C. W. Choi, S. W. Kang, I. S. Nam, D. H. Kim, M. K. Song, C. W. Kim and K. K. Park. 2008. Effects of level and degradability of dietary protein on ruminal fermentation and concentrations of soluble non-ammonia nitrogen ruminal and omasal digesta of Hanwoo steers. AsianAust. J. Anim. Sci. 21:392-403.

Ørskov, E. R. and P. McDonald. 1979. The estimation of protein degradability in the rumen from incubation measurements weighted according to rate passage. J. Agric. Sci. (Camb.) 92: 499-503.

Richards, C. J., A. F. Branco, D. W. Bohnert, G. B. Huntington, M. Macari and D. L. Harmon. 2002. Intestinal starch disappearance in steers abomasally infused with starch and protein. J. Anim. Sci. 80:3361-3368.

Richards, C. J., K. C. Swanson, S. J. Paton, D. L. Harmon and G. B. Huntington. 2003. Pancreatic exocrine secretion in steers infused postruminally with casein and cornstarch. J. Anim. Sci. 81:1051-1056.

Robinson, P. H. and R. E. McQueen. 1994. Influence of supplemental protein source and feeding frequency on rumen fermentation and performance in dairy cows. J. Dairy Sci. 77: 1340-1353.

Robinson, P. H., D. M. Veira and M. Ivan. 1998. Influence of supplemental protein quality on rumen fermentation, rumen microbial yield, forestomach digestion, and intestinal amino acid flow in late lactation Holstein cows. Can. J. Anim. Sci. 78:95-105.

SAS. 2002. Statistical analysis systems. User's guide: Statistics, Version 9.1 Edition. 2002. SAS Inst., Inc., Cary, NC, USA.

Smith, S. B. and J. D. Crouse. 1984. Relative contributions of acetate, lactate and glucose to lipogenesis in bovine intramuscular and subcutaneous adipose tissue. J. Nutr. 114: 792-800.

Swanson, K. C., C. J. Richards and D. L. Harmon. 2002. Influence of abomasal infusion of glucose or partially hydrolyzed starch on pancreatic exocrine secretion in beef steers. J. Anim. Sci. 80:1112-1116. 
Taniguchi, K., G. B. Huntington and B. P. Glenn. 1995. Net nutrient flux by visceral tissues of beef steers given abomasal and ruminal infusions of casein and starch. J. Anim. Sci. 73:236-249.

Van Straalen, W. M. and S. Tamminga. 1990. Protein degradation of ruminant diets. In Feedstuff evaluation. 1. Livestock. Feedingstuffs. Composition (Ed. J. Wiseman and D. J. A. Cole). Butterworths, London, UK, pp. 55-72.
Volden, H. and O. M. Harstad. 1995. Effect of rumen incubation on the true indigestibility of feed protein in the digestive tract determined by nylon bag techniques. Acta Agric. Scand., Sect. A, Animal Sci. 45:106-115.

Wright, D. E. and R. E. Hungate. 1967. Amino acid concentration in rumen fluid. Appl. Environ. Microbiol. 15:148-151. 